\title{
Functional diversity of soil microorganisms in the conditions of an ecological farming system
}

\author{
Danica Fazekašová*, Juraj Fazekaš \\ ${ }^{1}$ Department of Environmental Management, Faculty of Management, University of Prešov in Prešov, \\ Konštantínova 16, 08001 Prešov, Slovak Republic
}

\begin{abstract}
FAZEKAŠOvÁ, D., FAZEKAŠ, J., 2019. Functional diversity of soil microorganisms in the conditions of an ecological farming system. Folia Oecologica, 46: 146-152.

In the current study, we investigate the relationships among the soil functional diversity, physicochemical properties and heavy metals presence in an ecological farming system. The soil samples were collected from permanent research sites, from A soil horizons, at a depth from $0.05 \mathrm{~m}$ to $0.15 \mathrm{~m}$, in June 2018. In fresh soil samples, we evaluated the metabolic profiles of their microbial communities, using Biolog ${ }^{\circledR}$ Eco Plates. The research showed that the soil physical properties got adjusted after a long-term application of an ecological farming system and that the measured values were stabilised, reaching the levels comparable with the average values for the relevant soil type. It is necessary to devote a continual attention to soil reaction, because soil is naturally acidified through acid atmospheric fallout as well as through calcium uptake-off by plants. The values of the selected heavy metals in the monitored period did not exceed the limit values specified in the Act No. 220/2004 Coll. Based on the results of Shannon's diversity, we can conclude that the diversity in the investigated sites was low, from moderate to medium. The differences (3.26-3.36) among all 11 study localities were very small and not significant. There were determined the correlations between the soil functional diversity, soil physicochemical properties, and heavy metal contents. The average well colour development (AWCD) positively correlated with soil reaction and with $\mathrm{Mg}$ content and significantly negatively correlated with contents of $\mathrm{Hg}, \mathrm{Zn}$ and $\mathrm{Cu}$; equitability significantly positively correlated with soil reaction, $\mathrm{Mg}, \mathrm{AWCD}$ and Shannon's diversity. Spearman's correlation coefficients confirmed the positive correlation between Shannon's diversity and soil reaction, AWCD and Mg. In our study, no correlation was found between the functional diversity of microorganisms and the soil physical properties.
\end{abstract}

Keywords

AWCD, Biolog® system, bulk density, heavy metals, porosity, soil reaction

\section{Introduction}

Soil environment is a very complex and considerably diverse biological community providing a wide range of services for soil ecosystems. This is strategic for sustainable life of natural and managed ecosystems. The most active component of the soil biocenosis is microorganisms whose role in soil ecosystems is of key importance. Soil biodiversity is probably the essential factor for maintain- ing ecosystem functions in a disturbed environment. Soil biodiversity can be measured directly (species richness) or indirectly, through standardized procedures (various indexes). The state of the soil environment is, in addition to the soil activity, associated with the soil biota diversity. In terms of biology, soils belong to the most diverse habitats on the Earth. It has been estimated that $1 \mathrm{~g}$ of soil contains up to 1 billion bacteria cells comprising tens of ten-thousands of taxa, up to $200 \mathrm{~m}$ fungal hyphae,

*Corresponding author:

e-mail: danica.fazekasova@unipo.sk 
and a wide range of nematodes, earthworms, and arthropods (BARdgett and VAN Der Putten, 2014). Numerous studies have shown that intensive land use threatens soil biodiversity; simultaneously, land-use intensification and associated reductions in soil biodiversity contribute to several environmental problems, such as the eutrophication of surface water, reduced aboveground biodiversity, and global warming. This all can negatively affect human well-being (BENDER et al., 2016).

A series of physical, chemical and biological indicator parameters are used to assess soil health, and quality and changes in ecosystem sustainability (AvELLANEDATorres et al., 2018). Monitoring the structure of microbial communities and animals is a sensitive tool for assessment of soil quality and health. Generally, the microbial parameters in the soil ecosystems are considered to be the best indicators reflecting changing soil quality and properties, and thus, enabling early detection of soil degradation (RoMANIUK et al., 2011; MACCI et al., 2012). Spatial microbiological parameters, in particular, microbial biomass, basal respiration and the structure of microbial communities (DorAn and ZeIss, 2000), were suggested as possible indicators of soil quality and were used in national and international monitoring (YAO et al., 2000). The assay is based on the Biolog system using 31 different carbon sources to produce a metabolic profile of microorganisms (GARLAND and MiLls, 1991).

Long-term sustainability concerns are growing in agriculture owing to over- and under- application of fertilizers and owing to poor management of available resources. This results in soil health deterioration and declining crop productivity. Balanced and integrated use of organic and inorganic fertilizers is the most logical concept for managing and sustaining long term soil health and crop productivity (MeEna et al., 2019). WAMSLEY and SKLENIČKA (2017) reported that insufficient motivation of farmers to invest in soil conservation practices can initiate soil degradation, followed by an overall lower biological activity. Higher environmental quality, ecological farming system and the concept of ecological intensification have become essential parts of the sustainable development strategies related to soils in many countries (LIAO et al., 2007). It appears that increased soil biodiversity increases the sustainability and stability of ecosystems (BENDER et al., 2016). Choudhary et al. (2018) notes in its study that monoculture cultivation leads to a decrease of soil quality and biota. Sustainable intensification of cultivation systems is the best alternative to improve the soil quality index and to protect natural resources.

At the present time, there is little knowledge about soil development in the conditions of ecological farming systems, running on principles of soil maintenance aimed to increase the soil natural productivity, following the natural cycle as close as possible, with the highest possible reduction of external, mainly energetic, and chemical inputs (Duguma et al., 2010; FAZEKAŠoví, 2012). The present findings are difficult to compare due to the different soil-ecological conditions in which they were obtained.
The objectives of this study were (i) to analyse selected physical and chemical properties and heavy metal contents in soil; (ii) to assess the level of biodiversity of soil ecosystems, using the metabolic potential analysis by the Biolog system; (iii) to study the relationship between soil functional diversity and soil physicochemical properties and heavy metals in the conditions of an ecological system of soil farming.

\section{Materials and methods}

\section{Study area}

The investigated area Liptovská Teplička (4857'39.3'N, $20^{\circ} 05^{\prime} 49.9^{\prime \prime} \mathrm{E}$ ) is situated in the marginal region of northeastern Slovakia. The ecological farming system has been applied here since 1996. The area of Liptovská Teplička is situated in the Low Tatras National Park at an altitude ranging from 846 to $1,492 \mathrm{~m}$ asl. In terms of geomorphological division, it is a part of the sub-assemblies of the Král'ovohol'ské Mts (Mazúr and LuknIš, 1980). The whole area is situated in the mild zone with the sum of average daily temperatures above $10{ }^{\circ} \mathrm{C}$ ranging from 1,600 to 2,000 and the average precipitation of 700-1200 mm (Klimatický atlas Slovenska. Climate atlas Slovakia, 2015). The soil conditions are relatively homogeneous, the largest area being represented by Cambisols, mostly moderate and strongly skeletal, mainly in the subsoil. The second most common type of soil is Rendzic, moderate, shallow, and skeletal. In addition, Histosols occur in this territory. From the point of view of relief, the majority of the land is situated on the slopes. In the current crop structure, cereal acreage represents $33.3 \%$, potatoes $16 \%$ to $18 \%$ and fodder crops $49.8 \%$. Arable land is fertilised with a manure dosage of approximately $30 \mathrm{t} \mathrm{ha}^{-1}$ once in two years.

\section{Soil sampling, analyses and statistical analyses}

Soil samples were collected on 11 permanent research sites of Liptovská Teplička with ecological farming system, from A horizons, a depth of $0.05 \mathrm{~m}$ to $0.15 \mathrm{~m}$ (Fig. 1) in June 2018.

After homogenization, soil samples were manually crumbled, dried at room temperature, sieved $(\leq 2 \mathrm{~mm})$ and stored in polyethylene bags until their analysis. We evaluated soil reaction in $\mathrm{CaCl}_{2}$ solution $(5 \mathrm{~g}$ of soil mixed with $25 \mathrm{ml}$ of $0.01 \mathrm{~mol} \mathrm{CaCl}_{2}$ ) using a $\mathrm{pH}$ meter Mettler Toledo. The total contents of $\mathrm{Cd}$ and $\mathrm{Hg}$ were determined by atomic absorption spectrometry (AAS) and the total contents of $\mathrm{Cu}, \mathrm{Pb}, \mathrm{Zn}, \mathrm{Cr}, \mathrm{Mn}$ and $\mathrm{Mg}$ were determined by X-Ray fluorescence spectrometry following the methodology by Fiala et al. (1999). The assessed values of heavy metals in soils were compared to the limit values of Slovak soils (Act No. 220/2004). From physical soil parameters, we studied and evaluated the bulk density $(\mathrm{t}$ $\mathrm{m}^{-3}$ ) and porosity $(\%)$ in Kopecky physical cylinder with 


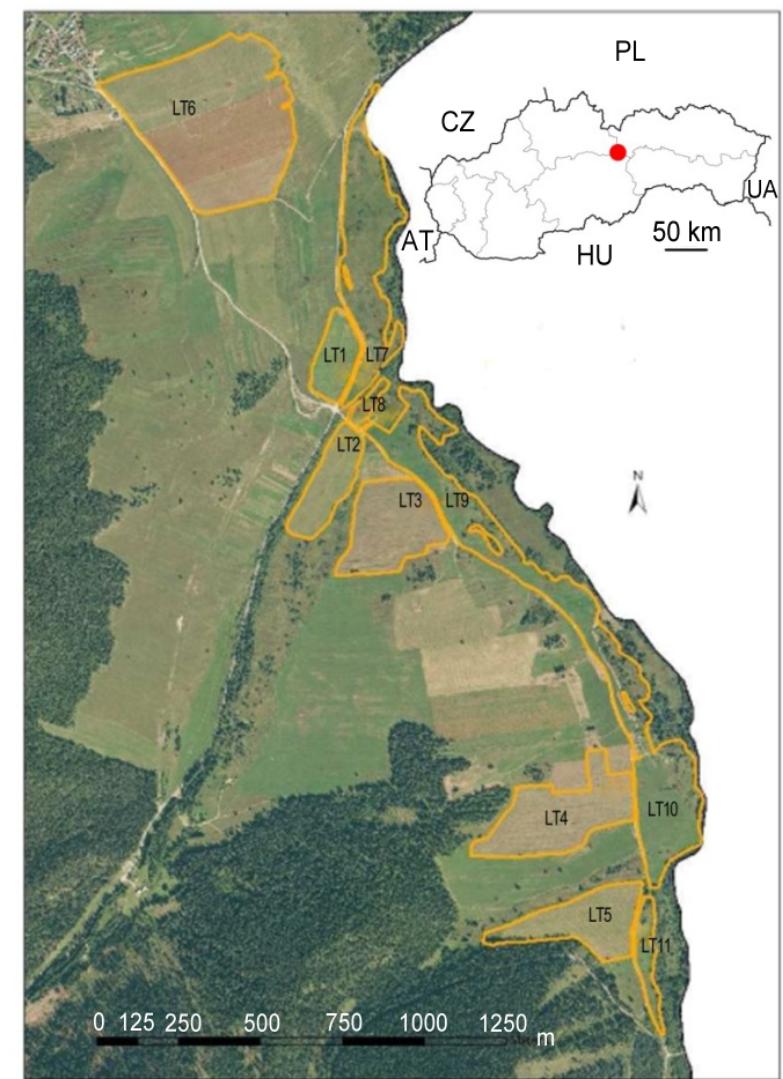

Fig. 1. The localization of sampling sites in Liptovská Teplička (Slovakia). a capacity of $100 \mathrm{~cm}^{3}$ (FIALA ET AL., 1999). In fresh soil samples, we evaluated metabolic profiles of microbial communities using Biolog ${ }^{\circledR}$ Eco Plates (GARLAND, 1997; HoFman et al., 2004). Microtiter plates with 31 different organic substrates were incubated with $150 \mu \mathrm{l}$ of the extract from the sample (dilution $1: 10,000$ in $0.9 \% \mathrm{NaCl}$ ) at $27{ }^{\circ} \mathrm{C}$ for 10 days. During the incubation of the samples, we used a device ELx808 TM Absorbance Microplate Reader to determine daily the value of the absorbance at $590 \mathrm{~nm}$ corresponding to the activity of microorganisms on various substrates. The data normalized parameter AWCD (average well colour development) was calculated according to GARLAND (1997) and functional diversity of soil microbiological communities was calculated for BIOLOG data by classical Shannon diversity index $\left(\mathrm{H}^{\circ}\right)$

$$
H^{\prime}=-\sum_{i=1}^{s} \frac{x i}{N} \log 2 \frac{x i}{N}
$$

(SHANnON, 1948). The results were evaluated based on scales: 1 extremely low $(<0.5), 2$ very low $(0.5-1.0), 3$ medium low (1.0-1.7), 4 low (1.7-2.5), 5 low to moderate (2.5-3.3), 6 medium (3.3-4.0), 7 moderately high (4.0-5.0), 8 high (5.0-7.0), 9 very high (7.0-10.0) and 10 extremely high $(>10.0)$.

Schematic diagram of the research methodology is shown in Fig. 2. The obtained data were processed statistically by the means of the STATISTICA 13 software and PAST 3. The level of significance between the soil properties was calculated using Spearman's correlation coefficient. The data were LOG transformed, prior to the analysis.

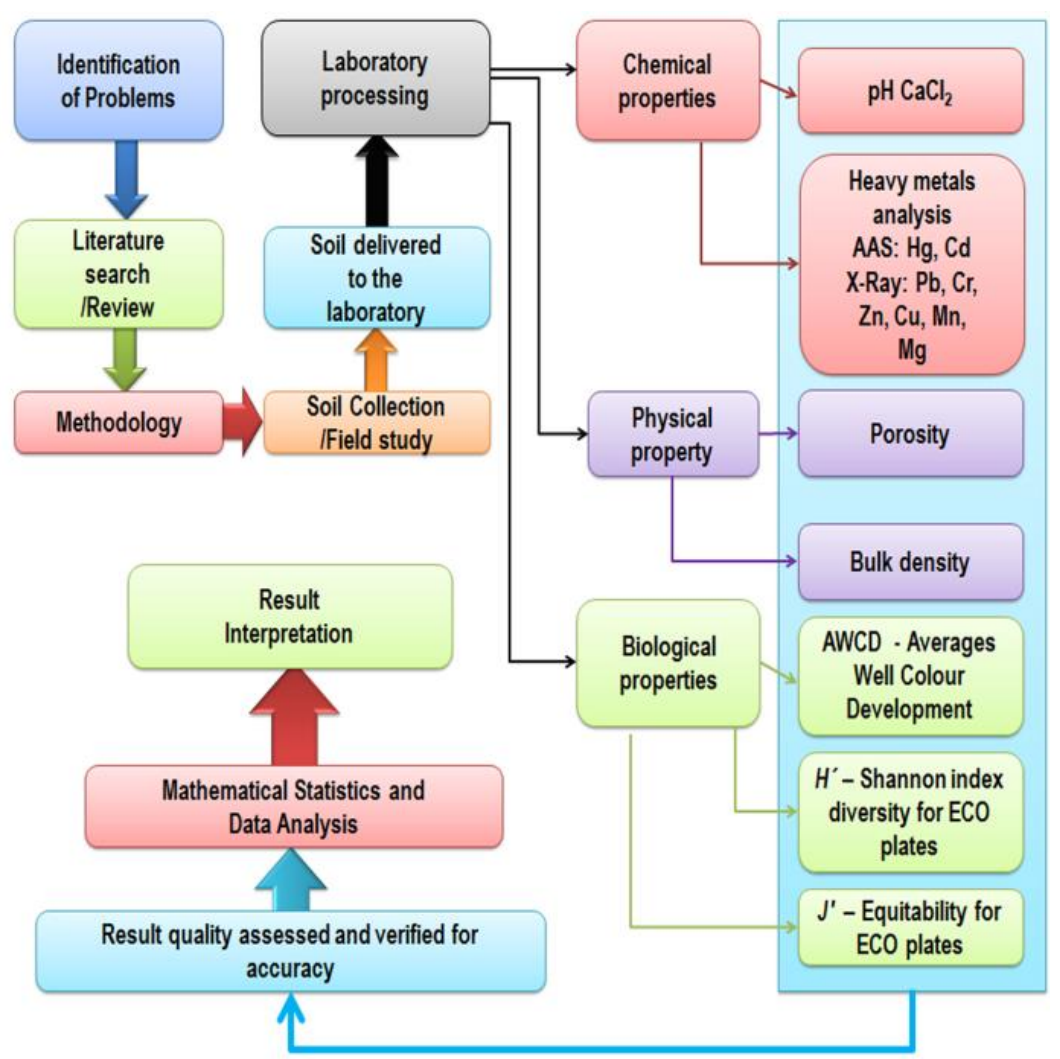

Fig. 2. Schematic diagram of the research methodology. 


\section{Results and discussion}

The descriptive statistics of the soil parameters are listed in Table 1. Soil reaction is considered to be one of the main chemical properties, as it affects all biochemical reactions in the soil environment (HoHL and Varma, 2010). Soil pH is a primary factor controlling the bacterial diversity and its community composition (BARGDETT, 2005; SHEN et al., 2013; YANG et al., 2019). The soil reaction in the investigated area with an ecological farming system ranged between $5.40 \pm 0.76$ (median \pm standard deviation), the range of values of the exchange soil reaction defines the soil as extremely acidic to neutral.

A commonly used soil physical characteristic expressing soil structural quality is soil bulk density $\left(\rho_{\mathrm{d}}\right)$. This parameter is often used in agronomic studies, as it indicates the presence of compacted layers. As such, it is commonly considered as a suitable trait for efficient measurement of soil carbon and nutrient stocks (BonDI et al., 2018). There is only little knowledge about bulk density, since the measurement of this parameter is demanding, as it is pointed out in the work by Premrov et AL. (2017).

Bulk density as an integral value of soil granularity, humus content and anthropogenic impacts on soil should not exceed the limits given for the individual soil types. Soil total porosity is the best indicator of soil structure quality, as the porosity can also influence soil microbial communities (Pagliai and Vignozzi, 2002).

Total porosity is closely related to bulk density. The total pore volume values should not fall below $38 \%$ for sandy soil and below $48 \%$ for clay-loam soil (LíšKA et al.,
2008). A long-term research has shown that ecological soil farming regulates bulk density of soil. The measured values of the bulk density were within the range $1.09 \pm$ $0.11\left(\mathrm{t} \mathrm{m}^{-3}\right)$. The values listed in Table 1 show that the porosity levels ranged within $57.32 \pm 4.42(\%)$, indicating optimum conditions created for the growth of most arable crops (defined with an interval from 55 to $65 \%$ ).

The evaluation showed that the content of heavy metals in soil with an ecological farming system did not reach the maximum values legalised for the Slovak Republic (Act No. 220/2004 Coll.) and that the measured values corresponded with the natural contents of the surveyed elements in soil and in base rocks. At the same time, in ecological systems, no anthropogenic pollution caused by applying chemical substances and sediments in soil is present (ČURLÍK and ŠEFČíK, 1999; MAKOVNÍKOVÁ et al., 2006).

For the analysis of changes in microbial communities, we used BIOLOG ${ }^{\circledR}$ Eco Plates. The most significant advantage of the Eco plates is that they contain 31 substrates (GARLAND, 1997). To calculate the Shannon diversity index (SHANNON, 1948), we used the absorbance at a given AWCD (average well colour development) in the samples investigated after 168 hours. The AWCD is an important and sensitive indicator reflecting the metabolic profiles of the soil microbial community. After $24 \mathrm{~h}$ of incubation, the rate of substrate utilization (colour development) at each site was accelerated for all soils. Figure 3 shows the results for the investigated soil samples. During 168 hours, we found out differences in the ability of microorganisms to metabolize the substrates. The highest

Table 1. Values of selected soil parameters, heavy metals, and average well colour development (AWCD) in Biolog® Eco Plates in the investigated areas Liptovská Teplička (Slovakia)

\begin{tabular}{|c|c|c|c|c|c|}
\hline Soil parameter & Mean & Min & Max & Median & $\begin{array}{l}\text { Standard } \\
\text { deviation }\end{array}$ \\
\hline $\mathrm{pH} / \mathrm{CaCl}_{2}$ & 5.51 & 4.40 & 6.90 & 5.40 & 0.76 \\
\hline$\rho_{d}\left(t^{-3}\right)$ & 1.07 & 0.86 & 1.22 & 1.09 & 0.11 \\
\hline Po $(\%)$ & 59.31 & 54.08 & 67.49 & 57.32 & 4.42 \\
\hline $\mathrm{Hg}\left(\mathrm{mg} \mathrm{kg}^{-1}\right)$ & 0.10 & 0.07 & 0.12 & 0.10 & 0.02 \\
\hline $\mathrm{Cd}\left(\mathrm{mg} \mathrm{kg}^{-1}\right)$ & 0.32 & 0.09 & 0.70 & 0.30 & 0.19 \\
\hline $\mathrm{Pb}\left(\mathrm{mg} \mathrm{kg}^{-1}\right)$ & 15.60 & 2.37 & 23.97 & 17.57 & 7.15 \\
\hline $\mathrm{Cr}\left(\mathrm{mg} \mathrm{kg}^{-1}\right)$ & 55.64 & 42.00 & 71.00 & 57.00 & 9.58 \\
\hline $\mathrm{Zn}\left(\mathrm{mg} \mathrm{kg}^{-1}\right)$ & 129.41 & 82.63 & 293.70 & 106.47 & 63.85 \\
\hline $\mathrm{Cu}\left(\mathrm{mg} \mathrm{kg}^{-1}\right)$ & 9.76 & 7.58 & 14.69 & 8.87 & 2.22 \\
\hline $\operatorname{Mn}\left(\mathrm{mg} \mathrm{kg}^{-1}\right)$ & 736.36 & 500.00 & 900.00 & 800.00 & 136.18 \\
\hline $\operatorname{Mg}\left(\mathrm{mg} \mathrm{kg}^{-1}\right)$ & 441.73 & 264.00 & 898.00 & 303.00 & 237.38 \\
\hline AWCD & 1.67 & 1.32 & 1.84 & 1.76 & 0.16 \\
\hline$H^{\prime}$ & 3.31 & 3.26 & 3.36 & 3.33 & 0.04 \\
\hline$J^{\prime}$ & 0.97 & 0.95 & 0.98 & 0.97 & 0.01 \\
\hline
\end{tabular}

$\rho_{\mathrm{d}}$ - bulk density, po - porosity, $\mathrm{H}^{\prime}$ - Shannon index diversity for ECO plates, J' - equitability for ECO plates, AWCD - average well colour development, limit value Act No. 220/2004 Coll.: $\mathrm{Hg}-0.5 \mathrm{mg} \mathrm{kg}{ }^{-1}, \mathrm{Cd}-0.7 \mathrm{mg} \mathrm{kg}^{-1}, \mathrm{~Pb}-70 \mathrm{mg} \mathrm{kg}{ }^{-1}, \mathrm{Cr}-70$ $\mathrm{mg} \mathrm{kg}{ }^{-1}, \mathrm{Zn}-150 \mathrm{mg} \mathrm{kg}^{-1}, \mathrm{Cu}-60 \mathrm{mg} \mathrm{kg}^{-1}$. 


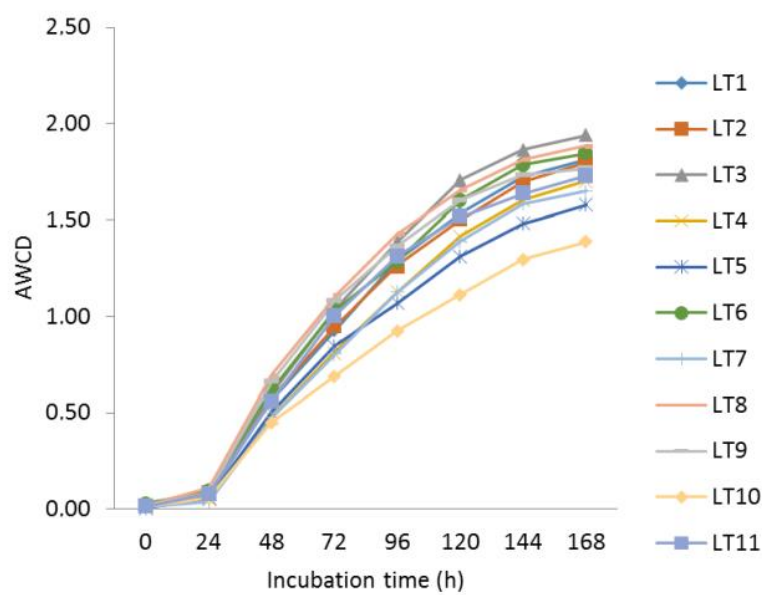

Fig. 3. Average well colour development (AWCD) of Biolog® Eco Plates (31 substrates) in the investigated area Liptovská Teplička (Slovakia).
Table 2. Spearman's correlation between functional diversity of microorganisms and physical soil parameters, chemical soil parameters and heavy metals

\begin{tabular}{cllc}
\hline & AWCD & $H^{\prime}$ & $J^{\prime}$ \\
\hline $\mathrm{pH} / \mathrm{CaCl}_{2}$ & $0.60^{* *}$ & $0.51^{* *}$ & $0.55^{* *}$ \\
$\rho \mathrm{\rho d}$ & 0.18 & 0.01 & -0.02 \\
$\mathrm{Po}$ & -0.18 & -0.02 & 0.02 \\
$\mathrm{Hg}$ & $-0.45^{*}$ & -0.27 & -0.31 \\
$\mathrm{Cd}$ & -0.13 & -0.04 & -0.06 \\
$\mathrm{~Pb}$ & -0.08 & 0.00 & -0.01 \\
$\mathrm{Cr}$ & -0.17 & -0.28 & -0.25 \\
$\mathrm{Zn}$ & $-0.39^{*}$ & -0.29 & -0.30 \\
$\mathrm{Cu}$ & $-0.46^{*}$ & -0.30 & -0.32 \\
$\mathrm{Mn}$ & -0.22 & -0.16 & -0.14 \\
$\mathrm{Mg}$ & $0.56^{* *}$ & $0.45^{*}$ & $0.50^{* *}$ \\
$\mathrm{AWCD}$ & & $0.90^{* *}$ & $0.90^{* *}$ \\
$H^{\prime}$ & & & $0.99^{* *}$ \\
\hline
\end{tabular}

but these correlations become negative at soil $\mathrm{pH}$ values higher than 8 . In our research, the soil $\mathrm{pH}$ was 4.40 (min) to 6.9 ( $\max )$, (Table 1$)$. There are strong negative correlations between the heavy metal contents and the microbial parameters (TISCHER et al., 2008). VINCENT et al. (2018) note that the moderate contamination with heavy metals altered the taxonomic and functional composition of the soil biota. The same has been confirmed in our research, nevertheless, with the measured values corresponding with the natural contents of the observed elements occurring in soil and in base rocks. These results indicate that these variables are potentially good indices of soil environmental quality, which is in accordance with the study GAŁĄZKa et al. (2017).

Soil total porosity was also found out to be one of the main factors influencing the soil bacterial and fungal community compositions (YANG et al., 2019). This result is not consistent with our findings. In our study, no correlation has been identified between the functional diversity of microorganisms and the soil physical properties.

\section{Conclusions}

The research showed that the soil physical properties at the inspected locality got modified after a long-term application of an ecological farming system. The measured values were found stabilised, reaching the levels comparable with the average values for the relevant soil type. It is necessary to pay a continual attention to soil reaction, because soil is naturally acidified due to acid atmospheric fallout as well as due to calcium uptake-off by plants. The values of the selected heavy metals obtained in the monitored period did not exceed the limit values set in the Act No. 220/2004 Coll. Based on the results of Shannon index diversity, we can conclude that the diversity at the investigated site is low, from moderate to medium. 


\section{Acknowledgements}

The study was supported by VEGA 1/0313/19 Ecosystem approach as a parameter of the modern environmental research of contaminated areas and KEGA 011PU4/2019 Implementation of environmental education and research into the teaching of management courses in the study program management.

\section{References}

Act No. 220/2004 Coll. on protection and use of agricultural soil (in Slovak Zákon č. 220/2004 o ochrane a využívaní pol'nohospodárskej pôdy). National Council of the Slovak Republic.

Avellaneda-Torres, L.M., León Sicard, T.E., Torres RoJAS, E., 2018. Impact of potato cultivation and cattle farming on physicochemical parameters and enzymatic activities of Neotropical high Andean Páramo ecosystem soils. Science of the Total Environment, 631-632: 1600-1610.

BARDGETt, R.D., 2005. The biology of soil. Oxford: Oxford University Press. 242 p.

Bardgett, R.D., Van der Putten, W.H., 2014. Belowground biodiversity and ecosystem functioning. Nature, 515. 505-511.

Bender, S.F., Wang, C., VAn der Heijden, M.G.A., 2016. An underground revolution: biodiversity and soil ecological engineering for agricultural sustainability. Trends in Ecology \& Evolution, 31 (6): 440-452.

Bondi, G., Creamer, R., Ferrari, Fenton, O., Wall, D., 2018. Using machine learning to predict soil bulk density on the basis of visual parameters: tools for in-field and post-field evaluation. Geoderma, 318: 137-147.

Choudhary, M., Jat, H.S., Datta, A., Yadav, A.K., SaPkot, T.B., Mondal, S., Meena, R.P., Sharma, P.C., Jat, M.L., 2018. Sustainable intensification influences soil quality, biota, and productivity in cereal-based agroecosystems. Applied Soil Ecology, 126: 189-198.

ČurLík, J., ŠEFČík, P., 1999. Geochemický atlas Slovenskej republiky [Geochemical atlas of the Slovak Republic]. Bratislava: Ministerstvo životného prostredia Slovenskej republiky.

Doran, J.W., ZeIss, M.R., 2000. Soil health and sustainability: managing the biotic component of soil quality. Applied Soil Ecology, 15 (1): 3-11.

Duguma, L.A, Hager, H., Sieghardt, M., 2010. Effects of land use types on soil chemical properties in smallholder farmers of central highland Ethiopia. Ekológia (Bratislava), 29 (1): 1-14.

FAZEKAŠOvá, D., 2012. Evaluation of soil quality parameters development in terms of sustainable land use. In CuRKovIC S. (ed.). Sustainable development - authoritative and leading edge content for environmental management. Rijeka: InTech, p. 435-458.

Fiala, K., Barančiková, G., BrečKová, V., Burik, V., Houšková, B., Chomaničová, A., KobZa, J., Litavec, T., Makovniková, L., Pechova, B., Varadiová, D., 1999. Záväzné metódy rozborov pôd. Čiastkový monitorovací system - Pôda [Obligatory methods of soil analysis. Par- tial monitoring system - Soil]. Bratislava: VÚPOP. 142 p.

GalązKa A., Gawryjolek K., Grządziel J., Frąc M., KsIĘŻAK J., 2017. Microbial community diversity and the interaction of soil under maize growth in different cultivation techniques. Plant, Soil and Environment, 63: 264-270.

GalązKa A., GawryjoleK K., Grządziel J., KsiężaK J., 2017. Effect of different agricultural management practices on soil biological parameters including glomalin fraction. Plant, Soil and Environment, 63: 300-306.

GARLAND, J.L., 1997. Analysis and interpretation of community-level physiological profiles in microbial ecology. FEMS Microbial Ecology, 24: 289-300.

Garland, J.L., Mills, A.L., 1991. Classification and characterisation of heterotrophic microbial communities on the basis of patterns of community-level-sole-carbonsource-utilization. Applied and Environmental Microbiology, 57: 2351-2359.

Gömöryová, E., Tóthová, S., Pichler, V., Homolák, M., KRIšŠÁK, V., GöMöRY, D., 2016. Wood ash effect on chemical and microbiological properties of topsoil in a Norway spruce stand one year after the treatment. Folia Oecologica, 43: 156-163.

Hofman, J., ŠvihÁleK, J., Holoubek, I., 2004. Evaluation of functional diversity of soil microbial communities - a case study. Plant, Soil and Environment, 50: 141-148.

Hohl, H., Varma, A., 2010. Soil: the living matrix. In Sherameti, I., Varma, A. (eds). Soil heavy metals. Soils Biology, 19. Berlin Heidelberg: Springer-Verlag, p. 1-19.

Klimatický atlas Slovenska. Climate atlas of Slovakia, 2015. Bratislava: Slovenský hydrometeorologický ústav. 132 p.

LiaO, M., XIE, X., 2007. Effect of heavy metals on substrate utilization pattern, biomass, and activity of microbial communities in a reclaimed mining wasteland of red soil area, Ecotoxicology and Environmental Safety, 66: 217-223.

LíšKa, E., Bajla, J., Candráková, E., FrančÁK, J., HrubÝ, D., Illeš, L., Korenko, M., NozdrovickÝ, L., Pospišil, R., ŠPÁNIK, F., ŽEMBERY, J., 2008. Všeobecná rastlinná výroba [General crop production]. Nitra: Slovenská pol'nohospodárska univerzita. $452 \mathrm{p}$.

Macci, C., Doni, S., Peruzzi, E., Masciandaro, G., MenNONE, C., Ceccanti, B., 2012. Almond tree and organic fertilization for soil quality improvement in southern Italy. Journal of Environmental Management, 95: 215-222.

Makovníková, J., Barančíková, G., Dlapa, P., Dercová, K., 2006. Anorganické kontaminanty v pôdnom ekosystéme [Inorganic contaminants in the soil environment]. Chemické Listy, 100: 424-432.

MAZÚR, E., LuKNIš, M., 1980. Regionálne geomorfologické členenie SSR [Regional geomorphological division of the Slovak Socialist Republic]. Bratislava: SAV, p. 54-55.

Meena, B.P., Biswas, A.K., Muneshwar Singh, Chaudhary, R.S., Singh, A.B. Das, H., Patra, A.K., 2019. Long-term sustaining crop productivity and soil health in maize-chickpea system through integrated nutrient management practices in Vertisols of central India. Field Crops Research, 232: 62-76.

Pagliai, M., Vignozzi, N., 2002. The soil pore system as 
an indicator of soil quality. Advances in GeoEcology, 35: 71-82.

Premrov, A., Cummins, T., Byrne, K.A., 2017. Bulk-density modelling using optimal power-transformation of measured physical and chemical soil parameters. Geoderma, 314: 205-220.

Romaniuk, R., Giuffre, L., Costantini, A., Bartoloni, N., NANNIPIERI, P., 2011. A comparison of indexing methods to evaluate quality of soils: The role of soil microbiological properties. Soil Research, 49: 733-741.

Rousk, J., BÅÅth, E., Brookes, P.C., Lauber, C.L., LozUpone, C., Caporaso, J.G., Knight, R., Fierer, N., 2010. Soil bacterial and fungal communities across a $\mathrm{pH}$ gradient in an arable soil. ISME Journal, 4 (10): 1340-51.

SHAnNon, C.E., 1948. A mathematical theory of communication. Bell System Technical Journal, 27: 379-423.

Shen, C., Xiong, J., Zhang, H., Feng, Y., Lin, X., Li, X., Liang, W., Chu, H., 2013. Soil pH drives the spatial distribution of bacterial communities along elevation on Changbai Mountain. Soil Biology and Biochemistry, 57: 204-211.

Tischer, S., TAnnaberg, H., Guggenberger, G., 2008. Microbial parameters of soils contaminated with heavy metals: assessment for ecotoxicological monitoring. Polish Journal of Ecology, 56: 471-479.
TORSviK, V., Øvreås, L., 2002. Microbial diversity and function in soil: from genes to ecosystems. Current Opinion in Microbiology, 5: 240-245.

Vincent, Q., Leyval, C., Beguiristain, T., Auclerc, A., 2018. Functional structure and composition of Collembola and soil macrofauna communities depend on abiotic parameters in derelict soils. Applied Soil Ecology, 130: 259-270.

Walmsley, A., SkleničKa, P., 2017. Various effects of land tenure on soil biochemical parameters under organic and conventional farming - Implications for soil quality restoration. Ecological Engineering, 107: 137-143.

YANG, Ch., LiU, N., ZhANG, Y., 2019. Soil aggregates regulate the impact of soil bacterial and fungal communities on soil respiration. Geoderma, 337: 444-452.

YaO, H., He, Z., Wilson, M.J., Campbell, C.D., 2000. Microbial biomass and community structure in a sequence of soils with increasing fertility and changing land use, Microbial Ecology, 40: 223-237.

Zhu, L., XiaO, Q., Shen, Y., Li, S., 2017. Microbial functional diversity responses to 2 years since biochar application in silt-loam soils on the loess Plateau. Ecotoxicology and Environmental Safety, 144: 578-584.

Received March 14, 2019 Accepted July 10, 2019 